\title{
A responsabilidade do afretador não armador por danos ambientais decorrentes da poluição marinha por óleo*
}

\section{The responsibility of the charterer not operator of a ship for environmental damages arising out of marine pollution by oil}

\begin{abstract}
Resumo
O presente estudo busca abordar a responsabilidade ambiental do afretador não armador, nas esferas civil, penal e administrativa, inclusive em sede de Tribunal Marítimo. $\mathrm{O}$ artigo procura esclarecer até onde se estende a responsabilidade do afretador na esfera ambiental, pelas avarias e danos ambientais, através do reconhecimento do risco da atividade marítima como nexo causal.

Palavras-chave: Contrato de afretamento. Responsabilidade ambiental. Direito marítimo.

Abstract

This study pursues to address the environmental responsibility of the charterer not operator in civil, criminal and administrative spheres, including the responsibility on the Maritime Court. The article seeks to clarify until where the responsibility of the charterer extends in the environmental sphere, for the environmental damage, by recognizing the risk of maritime activity as causation.
\end{abstract}

Keywords: Charter contract. Environmental responsibility. Maritime Law.

Recebido em: 23/03/2015.

Aprovado em: 22/06/2015.

1 Doutora e Mestre em Direito na Universidade Federal de Pernambuco (UFPE). Professora Adjunta da Universidade Federal de Pernambuco (UFPE). Auditora Ambiental Líder. Perita Ambiental Judicial. Coordenadora e Professora da Pós-Graduação em Direito Marítimo, Portuário e do Petróleo da UNINASSAU/PE. Professora da especializações em Direito Marítimo, Portuário e Ambiental da UNISANTOS/SP, Faculdade de Direito de Vitória/ES, UNIVALI/SC e UFRN. Presidente da Comissão de Direito Marítimo, Portuário e do Petróleo da OAB/PE. Membro da Comissão de Meio Ambiente da OAB/PE. Oficial do Conselho da Ordem do Mérito Naval/ Marinha do Brasil. Advogada no escritório Zanella Advogados \& Consultores, em Recife/PE. Pesquisadora da Linhares Geração em parceria com o Centro de Pesquisa e Projetos Tecnológicos (CPPT), em Projeto de Pesquisa e Desenvolvimento pela Agência Nacional de Energia Elétrica (ANEEL). 


\section{Introdução}

A Constituição da República Federativa do Brasil de 1988 estabelece a responsabilidade solidária entre o Poder Público e a coletividade na defesa e preservação do meio ambiente, além de estabelecer a responsabilidade tripa do poluidor em face dos danos ambientais.

Igualmente, as condutas e atividades consideradas lesivas ao meio ambiente sujeitarão os infratores, pessoas físicas ou jurídicas, a sanções penais e administrativas, independentemente da obrigação de reparar o dano.

Assim, a Constituição da República Federativa do Brasil de 1988, através da Emenda Constitucional n. ${ }^{\circ}$, de 15 de agosto de 1995 deu nova redação ao parágrafo único, do artigo 178 (cento e setenta e oito), que passou a permitir o uso de bandeiras estrangeiras na navegação de cabotagem no Brasil, desde que afretadas por empresas brasileiras.

Nesse diapasão, destacam-se a Lei de Ordenação do Transporte Aquaviário n. ${ }^{\circ}$ 9.432/97 e a Lei de criação da Agência Nacional de Transportes Aquaviários (ANTAQ) e do Conselho Nacional de Integração de Políticas de Transportes (CONIT), a Lei n. ${ }^{\circ} 10.233$, de 05 de junho de 2001.

Dessa forma o parágrafo único do artigo 178, da Constituição Federal, passou a ter a seguinte redação: "Na ordenação do transporte aquático, a lei estabelecerá as condições em que o transporte de mercadorias na cabotagem e a navegação interior poderão ser feitos por embarcações estrangeiras."

A abertura constitucional à navegação interior por embarcações estrangeiras foi decorrência da afirmação do Estado democrático de direito, igualmente chamado de Estado Constitucional, com a soma das liberdades conquistadas com o Estado Liberal mais a busca pela justiça social, do Estado Social (GOMES; VIGO, 2008, p. 20).

É comum o transporte de cargas, entre essas de óleo, ser realizada por embarcações estrangeiras afretadas por empresas brasileiras, o que pode representar um óbice quanto a responsabilidade integral por danos ambientais ocorridos em águas brasileiras.

Portanto, a problemática do presente artigo cinge-se a identificar até que ponto o afretador não armador, por se constituir como empresa brasileira, pode ser responsabilizado por danos ao meio ambiente ocasionados

por embarcações estrangeiras e, ainda, em quais esferas.
O objetivo principal é analisar os possíveis responsáveis pelo dano ambiental ocasionado pela poluição marinha decorrente de derramamento/vazamento de óleo. O tema do presente artigo foi defendido pioneiramente no III Congresso Nacional de Direito Marítimo, Portuário e Aduaneiro da OAB, em Santos - SP (CAMPOS, 2014).

Para o desenvolvimento deste artigo será imprescindível analisar as modalidades de responsabilização pela danosidade ambiental (cível, administrativa 'marítima’ e penal), a questão do poluidor e os tipos de contrato de afretamento.

\section{Da responsabilidade pela danosidade ambiental}

A Constituição da República Federativa do Brasil de 1988 , institui em seu art. $225, \$ 3^{\circ}$, a responsabilidade tripla em decorrência do dano ambiental, através da responsabilidade civil, administrativa e penal.

A responsabilidade civil ambiental, por força da Política Nacional do Meio Ambiente (Lei ${ }^{\circ}$ 6.938, de 31 de agosto de 1981), é objetiva por risco integral, não sendo necessário perquirir culta ou causas excludentes de responsabilidade. Inclusive se aplica a responsabilidade civil objetiva ao Estado, confira jurisprudência a respeito da matéria:

A responsabilidade civil do Estado, por omissão, é subjetiva, enfrenta exceções principais. Primeiro, quando a responsabilização objetiva do ente público decorrer de expressa previsão legal, como na proteção do meio ambiente (Lei 6.938/1981, art. $3^{\circ}, \mathrm{IV}, \mathrm{c} / \mathrm{c}$ o art. 14, $\$ 1^{\circ}$ ). A Administração é solidária, objetiva e ilimitadamente responsável, nos termos da Lei $6.938 / 1981$, por danos urbanístico-ambientais decorrentes da omissão do seu dever de controlar e fiscalizar, na medida em que contribua, direta ou indiretamente, tanto para a degradação ambiental em si mesma, como para o seu agravamento, consolidação ou perpetuação, tudo sem prejuízo da adoção, contra o agente público relapso ou desidioso, de medidas disciplinares, penais, civis e no campo da improbidade administrativa. (BRASIL, 2010)

Explica Herman Benjamin que a adoção da responsabilidade civil ambiental subjetiva levaria a impunidade do poluidor, pois haveria o risco de ser transferido para a sociedade o ônus de suportar os prejuízos decorrentes do dano ambiental; e a sociedade não dispõe dos instrumentos necessários para inibir a ocorrência de uma lesão ao meio ambiente, seja em razão da dificuldade de 
provar o nexo causal, seja pela dificuldade de acesso à justiça (BENJAMIN, 1998).

Por sua vez, a responsabilidade penal é subjetiva, pelo que se ressalta, a Lei $\mathrm{n}^{\circ} 9.605$, de 12 de fevereiro de 1998, que considera, no art. 54, crime causar poluição de qualquer natureza em níveis tais que resultem ou possam resultar em danos à saúde humana, ou que provoquem a mortandade de animais ou a destruição significativa da flora, punível com a pena de reclusão, de um a quatro anos, e multa.

A responsabilidade administrativa é reconhecida como objetiva hibrida, ou seja, caberia a exclusão dessa responsabilidade por fato exclusivo de terceiro, caso fortuito ou força maior. Nesse sentido a Lei no 9.605/1998, considera infração administrativa ambiental toda ação ou omissão que viole as regras jurídicas de uso, gozo, promoção, proteção e recuperação do meio ambiente, assim a simples conduta infracional já deve ser punida, independente da caracterização ou não do dano ambiental.

Importante suscitar que poderá haver a responsabilização administrativa do infrator em sede de processo administrativo marítimo próprio, ou seja, através da responsabilidade perante a Autoridade Marítima e/ou o Tribunal Marítimo.

No que tange a atuação da Capitania dos Portos e Costas em atos afetos ao meio ambiente, a doutrina e a jurisprudência se posicionam de forma pacifica, isso em decorrência de existir previsão legal nesse sentido.

Desse diapasão, cita-se o artigo $14, \S 4^{\circ}$, da Lei $n^{\circ}$ 6.938/1981, que estabelece: "Nos casos de poluição provocada pelo derramamento ou lançamento de detritos ou óleo EM ÁGUAS BRASILEIRAS, por embarcações e terminais marítimos ou fluviais, prevalecerá o disposto na Lei no 5.357/1967."

Igualmente, o artigo $70, \S 1^{\circ}$, da Lei $n^{\circ} 9.605 / 1998$, que estabelece: "São autoridades competentes para lavrar AI e instaurar processo administrativo os funcionários de órgãos ambientais integrantes do SISNAMA, bem como os agentes das Capitanias dos Portos, do Ministério da Marinha."

Neste momento há de ser interpretada a questão da competência do Tribunal Marítimo para o deslinde de acidentes marítimos envolvendo a poluição. $\mathrm{O}$ referido Tribunal é disciplinado pela Lei ${ }^{\circ} 2.180$, de 05 de fevereiro de 1954, que estabelece ser o Tribunal Marítimo órgão, autônomo, auxiliar do Poder Judiciário, com atribuições de julgar os acidentes e fatos da navegação marítima, flu- vial e lacustre e as questões relacionadas com tal atividade, e com jurisdição em todo o território nacional.

Independente da responsabilidade por atos de poluição ambiental na esfera administrativa, civil e penal, caso esse ato seja configurado como acidente ou fato da navegação, defende-se que poderá haver um processo administrativo marítimo em sede de Tribunal Marítimo, sem qualquer óbice legal, pois, entende-se que um dano ambiental pode ser classificado como acidente ou fato da navegação

Nota-se que de acordo com a Lei $\mathrm{n}^{\circ} 2.180 / 1954$, compete ao Tribunal Marítimo julgar os acidentes e os fatos da navegação, definindo-lhes a natureza e determinando-lhes as causas, circunstâncias e extensão; indicando os responsáveis e aplicando-lhes as penas estabelecidas nesta lei e propondo medidas preventivas e de segurança da navegação.

De acordo com Eliane Octaviano Martins, apesar de se consubstanciar em um órgão administrativo, o Tribunal Marítimo não exerce exclusivamente funções administrativas, mas também, atividades judicantes (MARTINS, 2008, p. 122).

Igualmente, a jurisdição do Tribunal Marítimo se estende sobre todo o território nacional e alcança toda pessoa jurídica ou física envolvida, por qualquer força ou motivo, em acidentes ou fatos da navegação, respeitados os demais instrumentos de Direito Interno e as normas do Direito Internacional (CAMPOS, 2011, p. 103).

No que concerne a competência administrativa, competente ao Tribunal Marítimo manter o registro geral: da propriedade naval; da hipoteca naval e demais ônus sobre embarcações brasileiras; e dos armadores de navios brasileiros.

Desta forma, referida Lei estabeleceu através de um rol exemplificativo os acidentes e os fatos da navegação nos artigos 14 e 15.

De acordo com o art. 14, consideram-se acidentes da navegação: naufrágio, encalhe, colisão, abalroação, água aberta, explosão, incêndio, varação, arribada e alijamento; avaria ou defeito no navio nas suas instalações, que ponha em risco a embarcação, as vidas e fazendas de bordo.

No mesmo sentido, a Convenção Montego Bay, em seu art. $1^{\circ}$, Decreto ${ }^{\circ} 1.530$, de 22 de junho de 1995, no artigo 221, ao tratar das medidas para evitar poluição ambiental resultante de acidentes marítimos, entende que acidente marítimo significa um abalroamento, encalhe 
ou outro incidente de navegação ou acontecimento a bordo de uma embarcação ou no seu exterior, de que resultem danos materiais ou ameaça iminente de danos materiais à embarcação ou à sua carga.

Percebe-se, portanto, que o rol de acidentes da navegação na CNUDM e na Lei de regência do Tribunal Marítimo, é exemplificativo.

Ratifica-se que um dano ambiental pode ser enquadrado, sem grande dificuldade, como uma avaria marítima, que enseja a responsabilidade em sede de Tribunal Marítimo. O mesmo raciocínio deve prevalecer com um defeito ou avaria no navio que coloque em risco a embarcação, as vidas e fazendas de bordo que venha a causar poluição marinha.

Por sua vez, a supra citada Lei, em seu art. 15, determina que se consideram fatos da navegação: o mau aparelhamento ou a impropriedade da embarcação para o serviço em que é utilizada, e a deficiência da equipagem; a alteração da rota; a má estimação da carga, que sujeite a risco a segurança da expedição; a recusa injustificada de socorro a embarcação em perigo; todos os fatos que prejudiquem ou ponham em risco a incolumidade e segurança da embarcação, as vidas e fazendas de bordo; e o emprego da embarcação, no todo ou em parte, na prática de atos ilícitos, previstos em lei como crime ou contravenção penal, ou lesivos à Fazenda Nacional.

Caso uma embarcação imprópria venha a transportar óleo e, consequentemente, a derramar a referida carga em águas jurisdicionais brasileiras, tal fato pode ser tipificado na alínea "a” do art. 15, supracitado. Ou seja, caso uma embarcação (incluindo as plataformas, uma vez em que a Lei ${ }^{\circ} 2.180 / 1954$, assim prevê) esteja mal aparelhada e venha ocasionar um acidente com carga perigosa, haverá, sem dúvida, um fato da navegação (CAMPOS, 2013).

Vale ressaltar que poluição ambiental é crime, conforme determina a Lei $\mathrm{n}^{\circ} 9.605 / 1998$, assim caso uma embarcação ocasione poluição marinha, estaria plenamente configurado o fato da navegação, previsto na aliena “f”, art. 15, da Lei n 2.180/1954.

São inúmeras as situações hipotéticas que podem relacionar a poluição marítima com acidentes e fatos da navegação, ainda, considerando que a Lei $n^{\circ}$ 2.180/1954 traz um rol exemplificativo desses.

Portanto, resta entendido que a competência do Tribunal Marítimo é julgar os acidentes e os fatos, não apenas os descritos na Lei $n^{\circ} 2.180 / 1954$, podendo haver uma atuação incisiva em atos de poluição ambiental considerados como acidentes e fatos da navegação.

\section{Do poluidor e da poluição ambiental}

A Política Nacional do Meio Ambiente (PNMA), em seu art. $3^{\circ}$, define meio ambiente de forma genérica e ampla, como "o conjunto de condições, leis, influências e interações de ordem física, química e biológica, que permite, abriga e rege a vida em todas as suas formas."

Em seguida traz o conceito de degradação e de poluição ambiental, sendo a primeira a alteração adversa das características do meio ambiente; e, por sua vez, a poluição, a degradação da qualidade ambiental resultante de atividades que direta ou indiretamente prejudiquem a saúde, a segurança e o bem-estar da população, criem condições adversas às atividades sociais e econômicas, afetem desfavoravelmente a biota ou as condições estéticas ou sanitárias do meio ambiente e lancem matérias ou energia em desacordo com os padrões ambientais estabelecidos.

Merece nota o fato de que a poluição ambiental é uma espécie de degradação decorrente de atividade humana. Por outro lado, a degradação ambiental pode ocorrer por fatores da natureza ou ocasionados pelo homem.

Por sua vez, a poluição marinha foi conceituada pela Convenção Montego Bay, em seu art. $1^{\circ}$, Decreto $n^{\circ}$ 1.530, de 22 de junho de 1995, e deve ser entendida como:

A introdução pelo homem, direta ou indiretamente, de substâncias ou de energia no meio ambiente marinho, incluindo estuários, sempre que a mesma provoque ou possa vir a provocar efeitos nocivos, tais como danos aos recursos vivos e à vida marinha, riscos à saúde do homem, entraves às atividades marítimas, incluindo a pesca e outras utilizações legítimas do mar, alteração na qualidade da água do mar, no que se fere à sua utilização e deteriorização dos locais de recreio.

De forma didática se propõe a divisão da poluição marinha, quanto às fontes geradoras, em dois grandes grupos: advindos de atividades de terra ou de mar. Por sua vez, a poluição marinha decorrentes de atividades marítimas, pode-se dividir em: por alijamento; decorrente de água de lastro; e por derramamento e/ou vazamento de óleo.

As mencionadas formas de poluição advindas de atividades marítimas são controladas por diversos órgãos, como a Autoridade Marítima, Agência Nacional de Vigi- 
lância Sanitária, Agência Nacional de Transportes Aquaviários, pelos órgãos integrantes do Sistema Nacional do Meio Ambiente (SISNAMA), com normas preventivas, demonstrando que a poluição pode e deve ser evitada, e que o meio ambiente marinho pode ser utilizado de forma sustentável.

Percebe-se a existência de uma série de regras e obrigações que visam evitar a poluição ou risco e ameaça de poluição por navios e embarcações em geral. Depreende-se que o transporte aquaviário é uma atividade amplamente regulada e fiscalizada, possuindo todos os requisitos para ser considerada uma atividade sustentável sob o aspecto ambiental.

Dessa forma, mesmo com todas as normas de prevenção, caso haja qualquer dano ambiental ao meio ambiente haverá a responsabilização do poluidor, que para a PNMA é: "a pessoa física ou jurídica, de direito público ou privado, responsável, direta ou indiretamente, por atividade causadora de degradação ambiental."

Em seguida, disciplina o artigo $14, \S 1^{\circ}$, sem prejuízo das penalidades definidas pela legislação federal, estadual e municipal, o não cumprimento das medidas necessárias à preservação ou correção dos inconvenientes e danos causados pela degradação da qualidade ambiental é o poluidor obrigado, independentemente da existência de culpa, a indenizar ou reparar os danos causados ao meio ambiente e a terceiros, afetados por sua atividade. Instituindo, assim, a responsabilidade objetiva, como anteriormente visto.

Portanto, a PNMA traz a possibilidade de identificação do poluidor direto $e$ indireto, onde o poluidor também é aquele que contribui para a poluição com consequente degradação do meio ambiente.

Ao se ponderar acerca da responsabilidade pelo dano ambiental do proprietário, armador e/ou do afretador não armador, deve-se considerar a identificação do poluidor direto e indireto.

\section{Das modalidades de contrato de afretamento}

O contrato de afretamento é o acordo pelo qual o proprietário (fretador) de um navio se compromete, percebendo em contrapartida, o frete, a transportar, ou a possibilitar que o afretador transporte, mercadorias em um determinado navio.

Desde já se esclarece que o armador pode ser entendido como pessoa física ou jurídica que, em seu nome e sob sua responsabilidade, apresta a embarcação com fins comerciais, pondo-a ou não a navegar por sua conta.

O contrato de afretamento não se confunde com contrato de transporte, pois o primeiro envolve tanto a locação do navio como a prestação de serviço de transporte, ou seja, se atribui o uso e a fruição do navio. Esse contrato pode ser de três tipos: a casco nu, por tempo $e$ por viagem.

O afretamento a casco nu é o contrato em virtude do qual o afretador tem a posse, o uso e o controle da embarcação, por tempo determinado, incluindo o direito de designar o comandante e a tripulação.

Já no afretamento por tempo, o afretador recebe a embarcação armada e tripulada, ou parte dela, para operá-la por tempo determinado. Por sua vez, no afretamento por viagem o fretador se obriga a colocar o todo ou parte de uma embarcação, com tripulação, à disposição do afretador para efetuar transporte em uma ou mais viagens.

A figura do armador da embarcação será alterada de acordo com o tipo de contrato de afretamento, por se alterar a gestão náutica e a comercial de uma embarcação.

\section{Dos princípios ambientais}

O desenvolvimento econômico em dissonância com a questão ambiental não se mostra mais possível, em face do reconhecimento pela Constituição Federal de 1988 do meio ambiente não poluído como direito fundamental. Dessa forma, a temática ambiental aparece como conteúdo e como limite das atividades econômicas, diante da supremacia da dignidade da pessoa humana e da primazia do direito à vida.

Nesse sentido, a sustentabilidade ambiental deve ser percebida através da necessidade humana de viver com saúde, dignidade e bem-estar, usufruindo, para tanto, dos bens ambientais dentro dos limites que não comprometam a existência desses recursos e não seja prejudicial ao meio ambiente.

Nesse contexto, com vistas a justificar a responsabilização do afretador não armador pelos danos ambientais, é imprescindível que sejam analisados os princípios ambientais fundamentais de tal possibilidade, com destaque aos seguintes: responsabilização e reparação das condutas e atividades lesivas ao meio ambiente; intervenção estatal obrigatória na defesa ambiental; e poluidor pagador. 
Para Álvaro Luiz Valery é essencial a análise dos princípios do Direito Ambiental são os princípios que auxiliam no entendimento e na identificação da unidade e coerência existentes entre todas as normas jurídicas que compõem o sistema legislativo ambiental, e são desses que se extraem as diretrizes básicas que permitem compreender a forma pela qual a proteção do meio ambiente é vista na sociedade (MIRRA, 1996, p. 50).

O princípio da responsabilização e reparação das condutas e atividades lesivas ao meio ambiente, previsto no Princípio 13 da Declaração do Rio sobre Meio Ambiente e Desenvolvimento (1992) estabelece que os Estados devem estabelecer em suas legislações a obrigação de o poluidor reparar o dano ambiental e de promover a indenização das possíveis vítimas.

O Brasil adotou na Lei de Política Nacional do Ambiental a responsabilidade objetiva ambiental (arts. $3^{\circ}$, IV, e 14), a qual foi ratificada pela Constituição Fede$\operatorname{ral}\left(\operatorname{art} .225, \$ 3^{\circ}\right)$

Esse princípio preconiza a importância de se responsabilizar os agentes da degradação ambiental. Nestes termos, por um ato poluidor, há possibilidade de responsabilidade simultânea nas esferas civil, penal e administrativa da pessoa física ou jurídica, em relação a um mesmo ato danoso.

O princípio da intervenção estatal obrigatória na defesa ambiental está assinalado no Princípio 17 da Declaração de Estocolmo de 1972, no Princípio 11 da Declaração do Rio de 1992 e no texto da Carta Magna, no caput do art. 225 e nos arts. 23, III,VI, VII, IX e XI, e 24, VI, VII e VIII.

Esse princípio pressupõe que o Poder Público tem a obrigação de atuar na esfera administrativa, legislativa e judicial na defesa do meio ambiente, constituindo um poder/dever, por conta da natureza indisponível desse bem. Contudo, como a própria Constituição Federal prevê que essa atividade estatal não é exclusiva, mas sim compartilhada com a participação direta da coletividade.

Por fim, oprincípio poluidor-pagador ou da responsabilizaçãotem sua previsãona Lei da Política Nacional do Meio Ambiente e na Constituição Federal. De acordo com o princípio poluidor-pagador, ou da responsabilização, o poluidor, pessoa física ou jurídica, é obrigado a recuperar ou indenizar o ambiente degradado, independentemente de culpa.

Tal princípio encontra-se presente na supracitada Lei, no art. $4^{\circ}, \mathrm{VII}$, e $\$ 1^{\circ}$ do art. 14 , que prescrevem:
Art. 4 A Política Nacional do Meio Ambiente, visará:

$[\ldots]$

VII - à imposição ao poluidor e ao predador da obrigação de recuperar e/ou indenizar os danos causados.

Art. 14. [...]

$\$ 1^{\circ}$ - Sem obstar a aplicação das penalidades previstas neste artigo, é o poluidor obrigado, independentemente da existência de culpa, a indenizar ou reparar os danos causados ao meio ambiente e a terceiros, afetados por sua atividade. O Ministério Público da União e dos Estados terá legitimidade para propor ação de responsabilidade civil e criminal, por danos causados ao meio ambiente;

A responsabilidade objetiva do poluidor pelos danos ambientais causados é, independentemente da existência de culpa, bastando apenas a ocorrência do fato danoso. Isto importa na reparação integral do prejuízo causado, que tem como objetivo primordial assegurar a recomposição do meio ambiente danificado, na medida do possível, no estado em que se encontrava antes da ocorrência do dano.

Celso Antonio Pacheco Fiorillo (2011, p. 92) identifica o princípio do poluidor pagador através de duas formas, preventiva e repressiva, a saber: busca evitar a ocorrência de danos ambientais e ocorrido o dano, visa à sua reparação.

Também o princípio do poluidor-pagador está expressamente agasalhado pelo art. $225, \S 3^{\circ}$, da Constituição Federal. Em nenhuma hipótese esse princípio significa pagar para poluir, seu significado refere-se aos custos sociais externos que acompanham a atividade econômica que devem ser internalizados, isto é, devem ser considerados pelo empreendedor e computados no custo do produto final (GRANZIERA, 2011, p. 70).

\section{A responsabilidade do afretador não armador e a posição do Superior Tribunal de Justiça}

Com vistas a considerar a possibilidade de responsabilidade do afretador não armador por danos ambientais marítimos, bem como em quais esferas essa poderia ocorrer, há de se analisar o Recurso Especial, interposto pela PETRÓLEO BRASILEIRO S/A - PETROBRÁS, $n^{\circ}$ 467.212 - RJ (2002/0106671-6), que teve como Relator o Ministro Luiz Fux.

A Comissão Estadual de Controle Ambiental (CECA) lavrou auto de infração imputando à Petrobrás 
multa por infringência ao inciso 2.1 da Tabela do Decreto $\mathrm{n}^{\circ}$ 8.974/86 cometida em 22/11/1991, consubstanciada no vazamento de 500 litros de petróleo do navio de bandeira Liberiana fretado pela Petrobrás.

Inconformada com a autuação ambiental a Petrobrás ajuizou Ação Anulatória de Débito Fiscal em face do Estado do Rio de Janeiro, objetivando ver declarada inexigível a multa ambiental, inscrita na Dívida Ativa, imposta por poluição de água e solo com substância não tóxica, conforme Decreto Estadual $n^{\circ}$ 8974/86, quando navio de bandeira Liberiana, fretado pela parte autora, transportava petróleo bruto para Angra dos Réis, sob os seguintes fundamentos:

1. O órgão Estadual que não possuía competência para a aplicação da penalidade, in casu, mas sim a Capitania dos Portos, por se tratar de embarcação, com base na o $\$ 4^{\circ}$, do art. 14 , da Lei $n^{\circ} 6.938 / 81$ e arts. $2^{\circ}$ e $3^{\circ}$, da Lei $n^{\circ} 5.357$, de 17 de novembro de 1967, vigentes à época do fato $(05 / 12 / 1990)$.

2. Que a responsabilidade por danos ambientais é exclusiva do proprietário, do comandante e do armador do navio da embarcação estrangeira, conforme art. $2^{\circ}$, do Decreto ${ }^{\circ}$ 83.540, de 04 de junho de 1979.

O juízo monocrático julgou improcedente o pedido deduzido na inicial sob o fundamento de que a responsabilidade em reparação por danos ambientais é objetiva, entre outros, conforme acórdão proferido em sede de Apelação pelo Tribunal de Justiça do Estado do Rio de Janeiro, com a seguinte ementa:

AÇÃO ANULATÓRIA DE AUTO DE INFRAÇÃO DE DÉBITO FISCAL. Multa ambiental aplicada pela FEEMA, sendo o auto de infração de 25.03.1993. Competência dos órgãos estatais de defesa do meio ambiente para fiscalização, sendo que a Constituição Federal possibilita aos entes federados a competência legislativa fiscalizatória para proteção ao meio ambiente e combate a poluição. Inexistência na Lei 5357/67 e Lei 6938/81 de impedimento a órgãos estatais para atividade fiscalizadora, sendo certo que o Decreto 99274/90, ao estruturar o SISNAMA, invoca entes estaduais como integrantes deste. Legitimidade da Petrobrás para ser autuada, independentemente do navio poluidor ter bandeira estrangeira, posto que estava por ela afretado sob a sua responsabilidade, não sendo o caso de incidência de convenção internacional. Inexistência de cerceamento, visto conter o auto de infração elementos suficientes a elaboração da defesa da autuada, o que efetivamente ocorreu. Incidência da Lei $6938 / 81$, art. $14, \S 1^{\circ}$, tratando-se no caso de responsabilidade objetiva. Sentença que se mantém.

Assim, o Recurso Especial foi interposto, com fulcro nas alíneas "a" e "c", do inciso III, do art. 105, da Constituição Federal, uma vez em que a matéria foi devidamente prequestionada, o recurso foi conhecido, cabendo ao STJ dirimir as seguintes controversas: se é da competência dos órgãos do SISNAMA ou da Capitania dos Portos a aplicação de penalidades pelo dano ambiental ocasionado por vazamento de óleo de navio estrangeiro em águas brasileiras; e se o pagamento da multa ambiental é de responsabilidade do proprietário do navio estrangeiro ou da Petrobrás, que o fretou para transportar o petróleo bruto.

Bem, no que concerne a competência fiscalizatória restou evidenciado que o $\$ 4^{\circ}$, do art. 14 , da Lei $n^{\circ}$ 6.938/81, não exclui a competência fiscalizatória e sancionatória dos órgãos estaduais de proteção ao meio ambiente, mas, ao contrário, consoante o art. $2^{\circ}$, da Lei ${ }^{\circ}$ 5.357/67, reforçou a referida competência. Desta forma o STJ afastou o pleito de incompetência da autoridade estadual que lavrou o auto de infração e impôs multa administrativa à Petrobrás.

A segunda problemática, na verdade, trata do objeto central do presente artigo. A questão está diretamente ligada ao fato de art. $2^{\circ}$, do Decreto $\mathrm{n}^{\circ} 83.540 / 79$, que regulamenta a aplicação da Convenção Internacional sobre Responsabilidade Civil em Danos Causados por Poluição por Óleo, de 1969, e dá outras providencias, estipular que a responsabilidade pelo dano ambiental provocado por navio estrangeiro é exclusiva proprietário, nos seguintes termos:

Art. $2^{\circ} \mathrm{O}$ proprietário de um navio, que transporte óleo a granel como carga, é civilmente responsável pelos danos causados por poluição por óleo no Território Nacional, incluído o mar territorial, salvo nas hipóteses previstas no $\$ 2^{\circ}$, do artigo III, da Convenção ora regulamentada.

Como explanado supra a PNMA abraçou a responsabilidade sem culpa ou objetiva, além de prever expressamente o dever do poluidor de recuperar e/ou indenizar os danos causados.

Da mesma, no caso em glosa, restou configurado que o risco da atividade desempenhada pela Petrobrás em causar danos ambientais consubstancia o nexo causal de sua responsabilidade, independentemente, de o derra- 
mamento de óleo ter ocorrido por culpa da embarcação afretada.

Por fim, entendeu o STJ que merecem tratamento diverso os danos ambientais provocados por embarcação de bandeira estrangeira contratada (afretada) por empresa nacional cuja atividade, ainda que de forma indireta, seja a causadora do derramamento de óleo, daqueles danos perpetrados por navio estrangeiro a serviço de empresa estrangeira, quando então resta irretorquível a aplicação do art. $2^{\circ}$, do Decreto $n^{\circ} 83.540 / 79$, quando a responsabilidade seria atribuída ao proprietário. No mais, ainda que, em ambos os casos haveria direito de regresso contra o culpado.

Portanto, 28 de outubro de 2003, o Recurso Especial foi julgado, onde acordaram os Ministros da Primeira Turma do Superior Tribunal de Justiça, os Ministros Teori Albino Zavascki, Humberto Gomes de Barros, José Delgado (voto-vista) e Francisco Falcão, na conformidade dos votos, após o voto-vista do Sr. Ministro José Delgado, por unanimidade, em negar provimento ao recurso, nos termos do voto do Sr. Ministro Relator, com a seguinte ementa²:

\section{Confira ementa completa: ADMINISTRATIVO. DANO AMBIENTAL. SANÇÃO ADMINISTRATIVA. IMPO- SIÇÃO DE MULTA. AÇÃO ANULATÓRIA DE DÉBI- TO FISCAL. DERRAMAMENTO DE ÓLEO DE EM- BARCAÇÃO ESTRANGEIRA CONTRATADA PELA PETROBRÁS. COMPETÊNCIA DOS ÓRGÃOS ESTA- DUAIS DE PROTEÇÃO AO MEIO AMBIENTE PARA IMPOR SANCÕOES. RESPONSABILIDADE OBJETIVA. LEGITIMIDADE DA EXAÇÃO. 1."[...] O meio ambiente,} ecologicamente equilibrado, é direito de todos, protegido pela própria Constituição Federal, cujo art. 225 o considera "bem de uso comum do provo e essencial à sadia qualidade de vida". [...] Além das medidas protetivas e preservativas previstas no $\$ 10$, incs. I-VII do art. 225 da Constituição Federal, em seu $\$ 30$ ela trata da responsabilidade penal, administrativa e civil dos causadores de dano ao meio ambiente, ao dispor: "As condutas e atividades consideradas lesivas ao meio ambiente sujeitarão os infratores, pessoas físicas ou jurídicas, a sanções penais e administrativas, independentemente da obrigação de reparar os danos causados". Neste ponto a Constituição recepcionou o já citado art. $14, \$ 1$ lo da Lei n. 6.938/81, que estabeleceu responsabilidade objetiva para os causadores de dano ao meio ambiente, nos seguintes termos: "sem obstar a aplicação das penalidades previstas neste artigo, é o poluidor obrigado, independentemente de existência de culpa, a indenizar ou reparar os danos causados ao meio ambiente e a terceiros, afetados por sua atividade." " [grifos nossos] (Sergio Cavalieri Filho, in "Programa de Responsabilidade Civil")

2. As penalidades da Lei $.^{\circ} 6.938 / 81$ incidem sem prejuízo de outras previstas na legislação federal, estadual ou municipal (art. 14, caput) e somente podem ser aplicadas por órgão federal de proteção ao meio ambiente quando omissa a
ADMINISTRATIVO. DANO AMBIENTAL. SANÇÃO ADMINISTRATIVA. IMPOSIÇÃO DE MULTA. AÇÃO ANULATÓRIA DE DÉBITO FISCAL. DERRAMAMENTO DE ÓLEO DE EMBARCAÇÃO ESTRANGEIRA CONTRATADA PELA PETROBRÁS. COMPETÊNCIA DOS ÓRGÃOS ESTADUAIS DE PROTEÇÃO AO MEIO AMBIENTE PARA IMPOR SANÇÕES. RESPONSABILIDADE OBJETIVA. LEGITIMIDADE DA EXAÇÃO.

$[\ldots]$

4. A competência da Capitania dos Portos não exclui, mas complementa, a legitimidade fiscalizatória e sancionadora dos órgãos estaduais de proteção ao meio ambiente. $[\ldots]$

8. Merecem tratamento diverso os danos ambientais provocados por embarcação de bandeira estrangeira contratada por empresa nacional

autoridade estadual ou municipal (art. $14, \S 2^{\circ}$ ). A ratio do dispositivo está em que a ofensa ao meio ambiente pode ser bifronte atingindo as diversas unidades da federação

3. À Capitania dos Portos, consoante o disposto no $\$ 4^{\circ}$, do art. 14, da Lei n. $^{\circ} 6.938 / 81$, então vigente à época do evento, competia aplicar outras penalidades, previstas na Lei n. ${ }^{\circ}$ 5.357/67, às embarcações estrangeiras ou nacionais que ocasionassem derramamento de óleo em águas brasileiras.

4. A competência da Capitania dos Portos não exclui, mas complementa, a legitimidade fiscalizatória e sancionadora dos órgãos estaduais de proteção ao meio ambiente. 5. Para fins da Lei no 6.938, de 31 de agosto de 1981, art 3o, qualifica-se como poluidor a pessoa física ou jurídica, de direito público ou privado, responsável, direta ou indiretamente, por atividade causadora de degradação ambiental. 6.Sob essa ótica, o fretador de embarcação que causa dano objetivo ao meio ambiente é responsável pelo mesmo, sem prejuízo de preservar o seu direito regressivo e em demanda infensa à administração, inter partes, discutir a culpa e o regresso pelo evento.

7. O poluidor (responsável direto ou indireto), por seu turno, com base na mesma legislação, art. 14 - "sem obstar a aplicação das penalidades administrativas" é obrigado, "independentemente da existência de culpa", a indenizar ou reparar os danos causados ao meio ambiente e a terceiros, "afetados por sua atividade".

8. Merecem tratamento diverso os danos ambientais provocados por embarcação de bandeira estrangeira contratada por empresa nacional cuja atividade, ainda que de forma indireta, seja a causadora do derramamento de óleo, daqueles danos perpetrados por navio estrangeiro a serviço de empresa estrangeira, quando então resta irretorquível a aplicação do art. $2^{\circ}$, do Decreto n. ${ }^{\circ} 83.540 / 79$

9.De toda sorte, em ambos os casos há garantia de regresso, porquanto, mesmo na responsabilidade objetiva, o imputado, após suportar o impacto indenizatório não está inibido de regredir contra o culpado. 10. In casu, discute-se tão-somente a aplicação da multa, vedada a incursão na questão da responsabilidade fática por força da Súmula 07/STJ.

11. Recurso especial improvido. 
cuja atividade, ainda que de forma indireta, seja a causadora do derramamento de óleo, daqueles danos perpetrados por navio estrangeiro a serviço de empresa estrangeira, quando então resta irretorquível a aplicação do art. $2^{\circ}$, do Decreto n. ${ }^{\circ} 83.540 / 79$

$[\ldots]$

Portanto, percebe-se que o entendimento exarado no caso em comento foi no sentido de ratificar a responsabilidade objetiva administrativa do afretador não armador, no caso a Petrobrás, independente da responsabilidade civil objetiva por risco integral, por haver configurado o nexo causal em decorrência do risco da atividade e por ser dispensável a averiguação da culpa.

Ainda há de se perquirir se poderia haver a responsabilidade administrativa marítima, principalmente em sede de Tribunal Marítimo. Como visto, o caso envolveu o derramamento de óleo por embarcação estrangeira afretada por empresa brasileira, em águas jurisdicionais brasileiras.

De acordo com a Lei $\mathrm{n}^{\circ} 2.180 / 1954$, compete ao Tribunal Marítimo julgar os acidentes e os fatos da navegação, definidos através de um rol exemplificativo os acidentes e os fatos da navegação nos artigos 14 e 15 da referida lei.

O artigo 10 da Lei em glosa disciplina as hipóteses e casos em que o Tribunal Marítimo exercerá jurisdição, assim, o Tribunal Marítimo tem competência, entre outros, para julgar acidente e fato da navegação envolvendo embarcação mercante de qualquer nacionalidade em águas brasileiras estrangeira; locatários de embarcações estrangeiras mercantes; toda pessoa envolvida, por qualquer forma ou motivo, em acidente e fato da navegação; e, ilhas artificiais, instalações estruturas, bem como embarcações de qualquer nacionalidade empregadas em operações relacionadas com pesquisa científica marinha, prospecção, exploração, produção, armazenamento e beneficiamento dos recursos naturais, nas águas interiores, no mar territorial, na zona econômica exclusiva e na plataforma continental brasileiros.

Questão envolvendo a vertente ambiental foi abordada recentemente pelo Tribunal Marítimo no Processo $n^{\circ} 27.050 / 12$, que trata do caso do vazamento de óleo durante operação de perfuração de poço, no Campo de Frade, pela plataforma "SEDCO 706". Inclusive, este posicionamento pioneiramente defendido que o referido Tribunal pode atuar em questões ambientais foi reconhecido pelo Tribunal Marítimo, tendo, inclusive, sido citado na decisão emanada em 15/10/13 pelo juiz Marcelo David, no Processo no 27.050/12, da seguinte forma:

Como cabe ao Tribunal Marítimo julgar o acidente da navegação, determinando sua natureza, extensão, causas e responsáveis, configurada a competência do Tribunal para o julgamento da poluição, mais uma vez. Inclusive esse foi o posicionamento doutrinário defendido com brilhantismo pela Dra. Ingrid Zanella, especialista na matéria, no III Workshop do Tribunal Marítimo, recentemente realizado. (Grifo nosso)

Portanto, o entendimento que o rol dos acidentes e fatos da navegação é exemplificativo é, ainda, uma interpretação conforme a Constituição Federal, por possibilitar que o Tribunal Marítimo atue de forma incisiva em questões ambientais marítimas.

\section{Considerações finais}

Constata-se que a depender do tipo de contrato de afretamento o afretador ou o proprietário poderá ter a gestão náutica da embarcação, constituindo-se como o armador.

Ainda que independente do personagem marítimo que atuará como armador, deverá haver a responsabilização ambiental pela caracterização do dano ambiental, bem como a sua reparação, considerando que o direito ao meio ambiente não poluído é reconhecido como direito humano e fundamental.

Desta forma, os danos ambientais decorrentes da poluição marinha por derramamento ou vazamento de óleo podem ensejar a tripla responsabilização ambiental.

Entretanto, a depender do tipo de contrato de afretamento, da área de navegação e da nacionalidade da embarcação, a responsabilização poderá ocorrer no âmbito civil, penal e administrativo, incluindo a responsabilidade administrativa marítima em sede de Autoridade Marítima e/ou de Tribunal Marítimo.

Portanto, o afretador não armador pode ser amplamente responsabilizado por danos ambientais, nas esferas civil e administrativa (e marítima), em decorrência do nexo causal estabelecido pelo risco da atividade, pela responsabilidade objetiva e por se configurar como poluidor indireto.

Deste modo, a lei deve ser interpretada com vistas a uma maior proteção ambiental marítima, que demanda de uma atuação incisiva e de responsabilização ampla pelos danos ambientais. 


\section{Referências}

BENJAMIN, Antonio Herman. O principio do poluidor-pagador. In: BENJAMIN, Antonio Herman V. (Coord.). Dano ambiental, prevenção, reparação e repressão. São Paulo: Revista dos Tribunais, 1998.

BRASIL. Superior Tribunal de Justiça. Recurso Especial. REsp 1071741/SP. Segunda Turma. Relator: Ministro Herman Benjamin. Brasília, 24 de março de 2009. Disponível em: <http://www.lexml.gov.br/urn/ urn:lex:br:superior.tribunal.justica;turma.2:acordao;re sp:2009-03-24;1071741-1075754>. Acesso em: 21 out. 2014.

CAMPOS, Ingrid Zanella Andrade. Direito constitucional marítimo. Curitiba: Juruá, 2001.

CAMPOS, Ingrid Zanella Andrade. A responsabilidade do afretador não armador. Disponível em: <http://www. congressomaritimosantos.com.br/palestras_documentos.php>. Acesso em: 21 out. 2014.

CAMPOS, Ingrid Zanella Andrade. O papel do tribunal marítimo da defesa do meio ambiente. In: WORKSHOP DO TRIBUNAL MARÍTIMO, 3., 2013. Anais... 2013. Disponível em: <https://www.mar.mil.br/tm/download/ palestra_workshopIII/workshopIII_ingrid_zanella.pdf $>$. Acesso em: 21 out. 2014.
CAMPOS, Ingrid Zanella Andrade. A atuação do Tribunal Marítimo em casos ambientais: responsabilidade administrativa marítima. Revista Portos e Navios, Rio de Janeiro, p. 1-20, 19 maio 2014. Disponível em: <http:// www.portosenavios.com.br/artigos 1/24269-a-atuacao-do-tribunal-maritimo-em-casos-ambientais-responsabilidade-administrativa-maritima $>$. Acesso em: 21 out. 2014.

FIORILLO, Celso Antonio Pacheco. Curso de direito ambiental brasileiro. 12. ed. São Paulo: Saraiva, 2011.

GOMES, Luiz Flávio; VIGO, Luis Rodolfo. Do Estado de direito constitucional e transconstitucional: riscos e precauções (navegando pelas ondas evolutivas do Estado e da justiça). São Paulo: Premier Máxima, 2008.

GRANZIERA. Maria Luiza Machado. Direito ambiental. São Paulo: Atlas, 2011.

MARTINS, Eliane Maria Octaviano. Curso de direito marítimo. 3. ed. Barueri: Manole, 2008.

MIRRA, Álvaro Luiz Valery. Princípios fundamentais do direito ambiental. Revista de Direito Ambiental, n. 2, p. 50, abr./jun. 1996. 